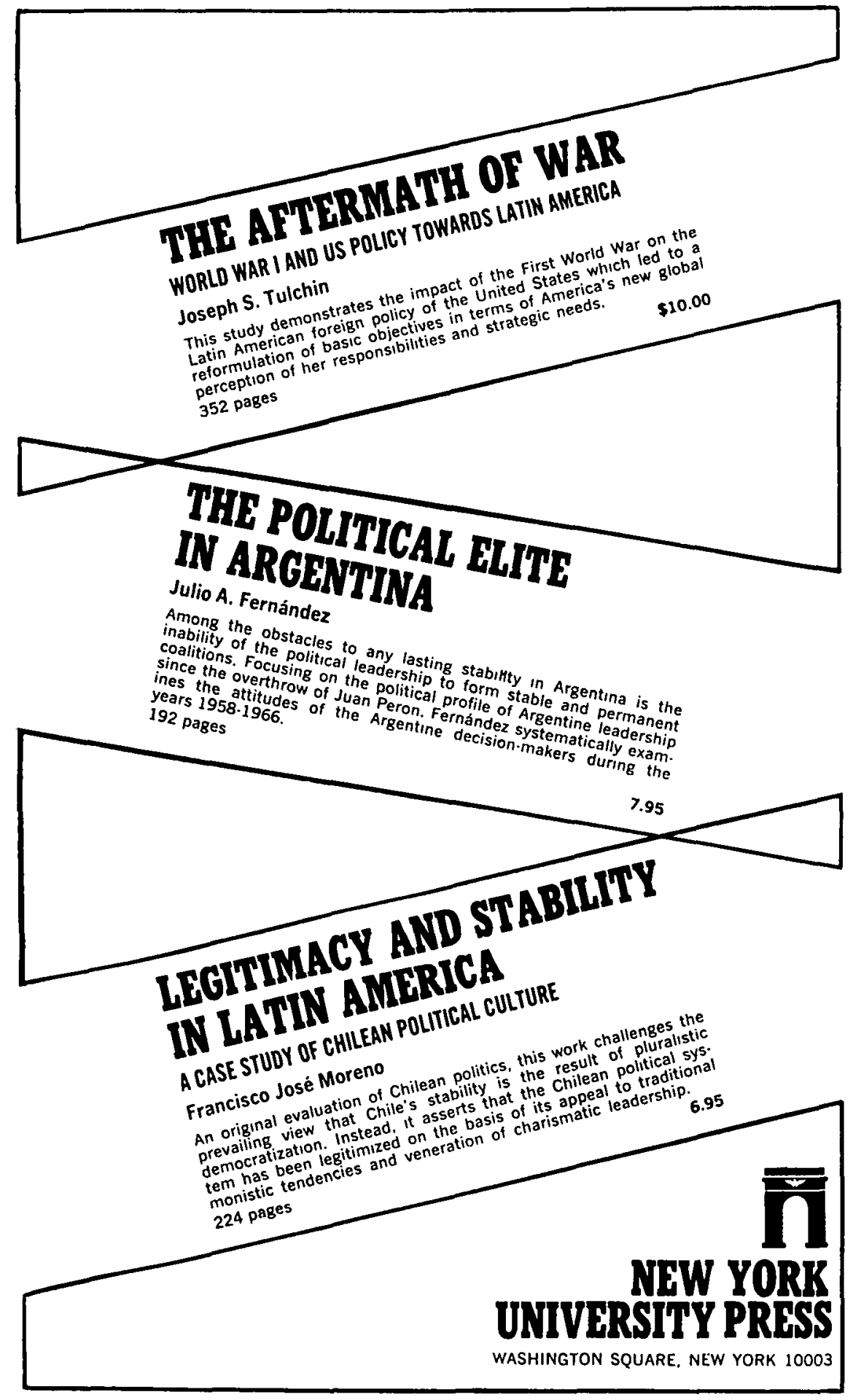




\section{MALLEA: TODO VERDOR PERECERÁ}

Edited by Donald L. Shaw

This is one of the most powerful novels to come out of Latin America. It is accompanied by an introductory essay combining the thoughts of modern criticism with biographical and bibliographical details of the author.

190 pages 1.05 flexi cover $\mathrm{fl} .50$ hard cover

\section{PALMA: TRADICIONES PERUANAS}

Edited by Pamela Francis

A selection of the 'tradiciones' written by this famous nineteenth century Peruvian writer in the original Spanish accompanied by an introduction to his life and work.
120 pages
$75 p$ flexi cover
fl.25 hard cover

\section{QUIROGA: CUENTOS ESCOGIDOS}

Edited by Jean Franco

"These tense, dramatic, short stories should awaken the interest of even the most somnolent student, and together with Professor Franco's introduction, which is a model of its kind, they will prove an admirable initiation into the literature of Latin America ". New Vida Hispanica
208 pages
£I.00 flexi cover
fl.50 hard cover

\section{CESAR VALLEJO : AN ANTHOLOGY OF HIS POETRY}

\section{J. Higgins}

An introduction to the work of Vallejo-probably the most important Spanish poet of the 20th Century - this book includes 90 poems covering the main stages of his poetic development. Notes explain various difficulties and the introduction includes a brief biography of the poet, a bibliography and a study of his work.
192 pages
$1 \cdot 25$ flexi cover
fl $\cdot 75$ hard cover

\section{SEVEN STORIES FROM SPANISH AMERICA}

G. Brotherston and Mario Vargas Llosa

Chosen for their literary quality, the stories offer a diversity of experience from the many different Spanish American nations. Each story is separately introduced. A glossary is provided and difficult passages are annotated.
110 pages
$75 p$ flexi cover
f1.25 hard cover

\section{SPANISH AMERICAN MODERNISTA POETS-A CRITICAL ANTHOLOGY}

\section{Edited by G. Brotherston}

An introduction discusses the modernista movement (1880 to 1918), and each poet is introduced separately; bio-bibliographical details are given together with some general appreciation of the poems. Notes, factual explanations and close literary criticism of the poems are included at the end of the book.
192 pages
fl.05 flexi cover
fl.50 hard cover

For further details of inspection copies please apply to College Department

PERGAMON PRESS LIMITED

Headington Hill Hall

Oxford $\mathrm{OX} 3 \mathrm{OBW}$

England

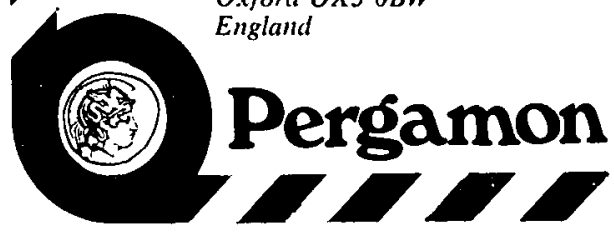




\section{The Old World and the New, 1492-1650}

\section{J. H. ELLIOTT}

This first book in the Cambridge Studies in Early Modern History Series evaluates the impact of the newly-discovered Americas on 16th and early 17th century Europe. - Mr. Elliott possesses a creative mind which ranges over all the questions historians have recently posed, and many more.'

New York Times Book Review

Cloth $\quad £ 1.75$ net Paperback 60p net

\section{Cambridge Latin American Studies Series}

Number 10

\section{Miners and Merchants in Bourbon Mexico, 1763-1810}

\section{A. BRADING}

In this pioneering study Professor Brading examines the means by which José de Gálvez, the dynamic minister of the Indies, hoped to transform colonial administration. $\mathrm{He}$ also analyses the structure of commerce and silver production, the role of Spanish immigration which controlled colonial trade and the great enterprises which dominated the mining industry.

$£ 5.20$ net

Number 12

\section{Politics and Trade in Southern Mexico, 1750-1821}

\section{BRIAN R. HAMNETT}

A detailed study of the relationship between the Spanish government and the trade and politics of southern Mexico during the late colonial period. This readable work is based on archival research and in both text and appendices the author provides detailed statistical information.

$£ 3.80$ net

Number 13

\section{Bolivia: Land, Location, and Politics since 1825}

\section{J. VALERIE FIFER}

This study examines the related aspects of location, accessibility, exploitation, attempted colonization, and boundary changes in Bolivia since 1825 , and reviews the poltical and economic geography of sectors of the country today.

To be published in September About $\mathbf{1 7 . 0 0}$ net

CAMBRIDGE UNIVERSITY PRESS 

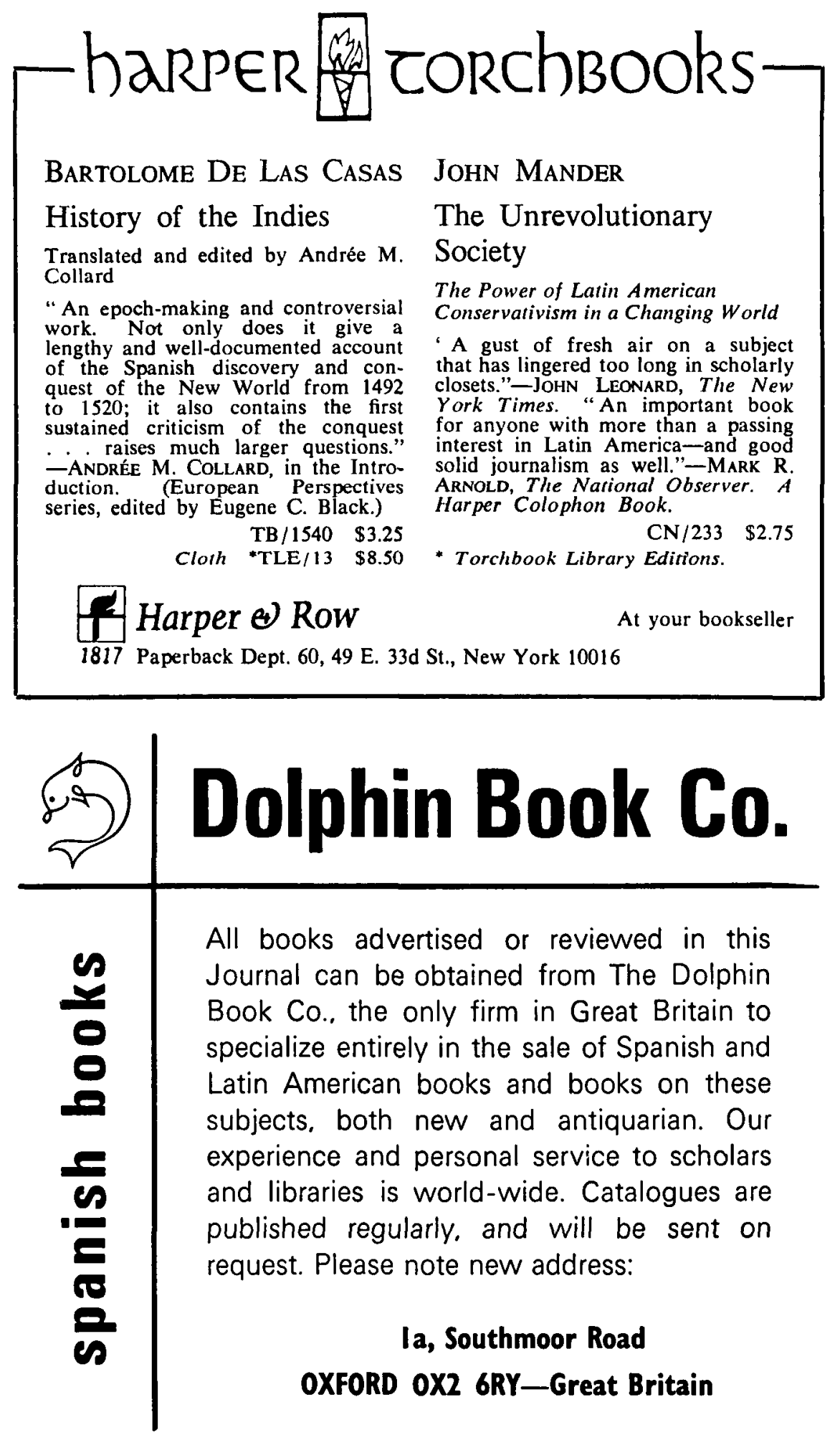


\section{Three \\ Latin \\ views \\ from \\ America... the 70's}

\section{The Alliance That Lost Its Way}

A Critical Report on the Alliance for Progress

by Jerome Levinson and Juan de Onis

"The Alliance for Progress is dead. It was, while it lasted, surely one of the nobler ventures of U.S. foreign policy. Levinson and de Onis, who saw it all for 10 years - the one as a high Alliance official, the other as The New York Times' Latin American correspondent - have put together a superb record of it."

The Washington Post

"This book belongs in all public and academic libraries... affords an education in the politics of foreign ald and the realities of our Latin American Policy."

A Twentieth Century Fund Study

Library Journal

$\$ 7.95$

\section{The Containment of Latin America}

A History of the Myths and Realities of the

Good Neighbor Policy

\section{by David Green}

"Green traces the course of U.S. - Latin American relations through the New Deal and the Truman administration. The discussion of the World War II period is valuable especially for its thesis that the war clinched Latin American dependence on the U.S. (contrary to the prevalent view that it catalyzed autarchic industrial growth) ... Lucid, straightforward research."

The KIrkus Reviows

$\$ 10.00$

\section{The Rockefeller Report On The Americas}

"If the traditional U.S. policy goal of encouraging stable economic and social development south of the border is still sound, the last decade has proven that the means to it are still poorly understood. And the Rockefeller commission has shown a refreshing tendency to pay attention to the realities of Latin America too often ignored in the often naive policies of the sixties."

The Wall Street Journal Cloth, \$5.95 Paper, \$1.95

\section{Q QUADRANGLE BOOKS}

A Subsidiary of The New York Times, Chicago 60611 


\section{Finuncing Development in Latin America}

\section{Edited by Keith Griffin}

\section{A volume in the Problems in Focus series}

The first detailed study of the way in which Latin American Republics have attempted to finance economic growth, discussing fiscal and monetary policy, private savings, foreign aid and private foreign investment. A great deal of new material has been utilised and much scattered evidence has been collected for the first time and presented in a systematic way.

\section{Macmillan}

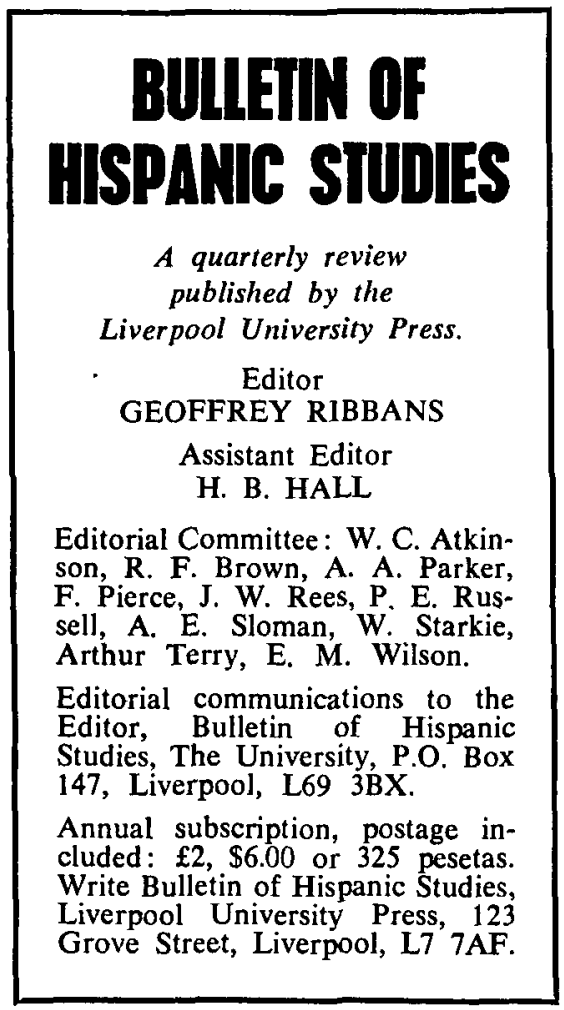

\section{JOURNAL OF LATIN AMERICAN STUDIES}

is one of over 50 learned journals published by Cambridge University Press.

A descriptive catalogue of Cambridge journals including details of back volumes is a vailable from the London and New York offices of the Press.

Cambridge journals may be ordered from a bookseller or direct from the publishers.

\section{Cambridge University Press}

Bentley House, 200 Euston Road

London, NW1 2DB

American Branch: 32 East 57th Street

New York, N.Y.10022 


\section{NOTES FOR CONTRIBUTORS}

Contributions are invited from all parts of the world. Articles should generally not be more than 8,000 words long, and two copies, typed with double-spacing. should be submitted. Diagrams and maps may be included by arrangement with the editors. The journal is published in English, but articles written in other languages will be considered, and arrangements made as required for translation into English. Contributors should keep one copy of the typescript for use in correcting proofs.

All contributions and editorial correspondence should be addressed to lournal of Latin American Studies, Institute of Latin American Studies, 31 Tavistock Syuare, London. WCiH $9 \mathrm{HA}$.

Each contributor will receive, free of charge, 25 offiprints of his article and a copy of the issue of the journal in which it appears.

\section{CONTRIBUTORS TO THIS ISSUE}

1) Shepard Formax is Assistant Professor of Anthropology at the University of Chicago.

DR Jas Bazast is Professor in the Centre of Historical Studies, El Colegio de México.

DR Peter Cor is a Lecturer in the Department of Anthropology and Sociology at Monash University.

1) Chartes A. Hate is Professor of Latin American History at the University of Jowa.

DR Austalr Hesiessy is Professor of History at the University of Warwick. 


\section{Journal of}

\section{Latin American Studies}

Volume 3 Part I May 1971

\section{OBITUAR Y}

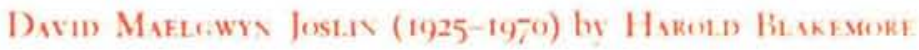

\section{ARTICLES}

Suepard Formas: Disunity and Discontent: A Studs of Peasint Political Movements in Brazil

Is Bazast: The Division of Some Mexicin Haciendax during the Liberal Revolution, $185^{6}-1862$

Petro (ios: A Watershed in Mexican Rural History: Sume Thoughts on the Reconciliation of Conflicting Interpretations

Cinstras A. Hat.e: The History of Ideas: Substantive and Methodological Aspects of the Thought of Leopolda \%ea

Atustair Hevxessy: Artists, Intellectuals and Revolution: Recent Books on Mexico (Review Article)

\section{REVIEWS by}

Eugenio P'ereira Salas, 89-90; A. G. Ford, g0-92: Emanuel de Kadt, 92-94:

l'eter Rivière, 94-95: Thomas E. Skidmore, 15-97; Stanley J. Stein. 9;-100: Peter Flvnn, too-104; Peter Calvert, 104-105: Ciorden Conncll Smith. 105-106: Alan Angell, 106-108: David J. Robinson, w4-110.

\section{BOOK NOTICES by}

Bernard Naslor, 111; Harold Blakemore, 111-112; H. C. Allen, 112; Henrs Kamen, 112-113; Peter Rivière. 11;-114; D. A. (;. Waddell, 14: Clifford T. Smith. 114-115: Brian Roberts, 115-116.

\section{CAMBRIDGE UNIVERSITY PRESS} Bentley House, 200 Euston Road. London NW ${ }_{12}$ DB American Branch: 32 East 57th Street, New York, N.Y. 10022

Single parts $\mathbf{E}_{1} .80$ net in U.K. (\$5.50 in U.S.A.)

Subseription price $\mathbb{C}_{2.50}$ tet in U.K. (\$8.50 in U.S.A.) 